\title{
The silent suffering women-a population based study on the association between reported symptoms and past and present infections of the lower genital tract
}

\author{
M Jonsson, R Karlsson, E Rylander, E Bodén, K Edlund, M Evander, Å Gustavsson, \\ G Wadell
}

\begin{abstract}
Objectives-To assess the prevalence of lower genital tract symptoms and the association between reported symptoms and past and present signs of sexually transmitted diseases (STD) in young women.
\end{abstract}

Design-All women belonging to the 19-, 21-, 23- and 25-year age cohorts and living in the catchment area of the community health centre, were invited by mail to take part in a population-based study. The participants answered a structured questionnaire and a gynaecologic examination was performed. Samples for wet smear, cervical Pap smear, HPV DNA determination and Chlamydia trachomatis culture were taken at the gynaecologic examination. The presence of genital warts was noted. A blood sample was analysed for antibodies against $\boldsymbol{C}$ trachomatis and HSV-2.

Setting-The community health care centre was located in Umeå, a city in Northern Sweden.

Results-Of the 886 women who were eligible, $611(70 \%)$ participated in the investigation. One out of four women reported symptoms from the lower genital tract. The most commonly reported symptoms were itching, followed by discharge, and soreness. The most commonly reported STD was $C$ trachomatis (15\%). The most prevalent present STD was HPV infection $(\mathbf{2 0 \%})$ whereas $C$ trachomatis infection could be isolated from $2 \cdot 7 \%$ of the women. Antibodies against $C$ trachomatis and HSV-2 were present among $22 \%$ and $6 \%$ of the women, respectively. There was a significant correlation between the women's complaint of vaginal discharge and previous $C$ trachomatis infection, lack of lactobacilli and presence of leucocytosis in wet smear.

Conclusions-We have in a populationbased study of young healthy women found that one out of four women had some kind of lower genital tract complaint. Itching was the most commonly reported symptom and was associated with pseudohyphae and acetowhite patches. Reported vaginal discharge and soreness were associated with the history of a past $C$ trachomatis infection and signs of a disturbed vaginal flora.

(Genitourin Med 1995;71:158-162)
Keywords: population-based study; women; symptoms; C trachomatis; HPV; HSV-2; chlamydia antibodies; wet smear; STD

\section{Introduction}

To our knowledge, no population-based survey has been published on the prevalence of reported symptoms from the lower genital tract in women and the association between clinical findings and symptoms. Prevalence studies are usually based on women seeking medical advice, and prevalence of symptoms tend to vary with the study population and the clinical setting. In a university hospital adolescent clinic in San Francisco, 23\% of women attended because of lower genital tract complaints. ${ }^{1}$ A family-planning clinic in the UK reported that $38 \%$ of women had lower genital tract symptoms. ${ }^{2}$ Eight percent of women attending a primary health care clinic in Sweden consulted for vaginal discharge, ${ }^{3}$ and the corresponding figure for a hospital-based practice in Boston was $30 \% .^{4}$ In order to avoid the bias caused by the clinical setting, a population-based study of young women was performed, with the aim of determining the prevalence of lower genital tract symptoms and the association with clinical findings.

\section{Material and methods}

Study population

Those eligible for inclusion in the study were all women belonging to the 19-, 21-, 23- and 25 year-old age cohorts and registered in September 1989 as living in the primary health care area of Ålidhem community centre in Umeå, a city in Northern Sweden with a population of 91000 . Umeå is a regional centre for education and administration, and as the primary health care centre of the community is close to the University, students compose a large proportion of the patient population.

The women received a written invitation outlining the purpose of the study and offering a gynaecologic examination with a test for chlamydia infection. Of the 886 women, 205 refused but agreed to be interviewed by telephone. The following reasons were given for not participating: the woman had recently consulted a gynaecologist $(n=90)$, she had permanently moved out of the area $(n=70)$, she had never had sexual intercourse $(n=$ 23), she was pregnant and had recently participated in maternal health care $(n=18)$, or could give no specific reason $(n=4)$. The non-participants did not differ from the 
Table 1 Distribution of the study population by age and mode of participation

\begin{tabular}{lllll}
\hline Age (years) & $\begin{array}{l}\text { Total population } \\
n=886(\%)\end{array}$ & $\begin{array}{l}\text { Attenders } \\
n=611(\%)\end{array}$ & $\begin{array}{l}\text { Telephone- } \\
\text { inverview } \\
n=205(\%)\end{array}$ & $\begin{array}{l}\text { Non attenders } \\
n=70(\%)\end{array}$ \\
\hline 19 & $113(13)$ & $70(12)$ & $35(17)$ & $8(11)$ \\
21 & $253(28)$ & $168(27)$ & $63(31)$ & $22(31)$ \\
23 & $298(34)$ & $228(37)$ & $55(27)$ & $15(22)$ \\
25 & $222(25)$ & $145(24)$ & $52(25)$ & $25(36)$ \\
\hline
\end{tabular}

participants in age (table 1), social background or education, and few of them $(1 \cdot 4 \%)$ reported an earlier chlamydia infection. In addition, there were 70 women who could not be reached at all, but as their ages were known the age distribution of this subgroup could be calculated, which did not differ from that of the participants. The study was approved by the local Medical Ethical Committee.

\section{Interview}

All women were interviewed and examined by the same registered midwife (M.J.). The women answered the questionnaires regarding their previous genital infections and the presence of lower genital tract symptoms during the preceding 6 month period, in the presence of the midwife in case any clarification of the questions was needed.

\section{Clinic examination and specimen collection}

The gynaecological examination included gross visual inspection of the anogenital area and the presence of exophytic genital warts, papillomatous structure, meaning a symmetrical lesion consisting of small papillary projections involving the medial aspects of the labia, introitus, or lower vagina and fissures in vulva were noted. An acetic acid solution (5\%) was applied on the vulva 2 minutes before evaluation with a colposcope (ZEISS OMPI). Acetowhite patches in vulva as described by Pixley et $a l^{5}$ were recorded as present or not present. A vaginal speculum was introduced and the presence of cervical ectopy was noted, defined as any $(>5 \mathrm{~mm}$ ) visible outgrowth of columnar epithelium from the endocervical canal.

Specimens for human papilloma virus (HPV) DNA detection were collected by scraping a cotton-tipped swab over ectocervix uteri. The cells were suspended in a plastic tube with $1.5 \mathrm{ml}$ STE $(0.1 \mathrm{M} \mathrm{NaCl}, 10 \mathrm{mM}$ Tris-HCL-pH 8.0, $1 \mathrm{mM}$ EDTA) and were frozen at $-20^{\circ} \mathrm{C}$. Samples were evaluated at the Department of Virology, University of Umeå using a previously described two-step PCR method. ${ }^{6}$

A wooden spatula and a cotton-tipped swab were used to collect the exocervical cytologic samples with emphasis on the squamocolumnar junction. Smears for cytological analysis were prepared and stained by the Papanicolaou method and evaluated at the Department of Cytology, University of Umeå.

Samples for Chlamydia trachomatis culture were taken from three locations; the endocervical canal and the surface of the cervical portio (Cytobrush Medscand AB, Sweden), the urethra with an ENT swab. All samples from one woman were immersed in one tube containing 2-SP and kept at $+4^{\circ} \mathrm{C}$ before transport to the Department of Virology, University Hospital of Umeå for analysis. C trachomatis organisms were isolated on cycloheximide treated McCoy cells. ${ }^{7}$

For preparation of wet smears, a sample of vaginal fluid was collected with a cottontipped swab and placed on two glass slides. Saline solution $(0.9 \%)$ was added to one sample and $10 \%$ potassium hydroxide $(\mathrm{KOH})$ to the other and the slides were examined by light microscope. In the saline preparation, the presence of lactobacilli, clue cells, trichomonads and leukocytes were noted. Clue cells are exfoliated squamous epithelial cells that appear under light microscope to be heavily stippled and have a granular appearance at the borders. If more than one clue cell in each of five low-power fields was present it was recorded. It was also noted if the number of leucocytes exceeded epithelial cells per five high power field. In the $\mathrm{KOH}$ preparation, the presence of fishy odour and pseudohyphae was noted.

Chlamydia antibodies in serum were determined by microimmunofluorescence (MIF) technique. Sera were absorbed by aggregated gammaglobulin to remove any rheumatoid factor and inactivated at $56^{\circ} \mathrm{C}$ for one hour. They were then screened for antibody activity at a dilution of $1 / 16$ with three different antigens in a cluster. One antigen dot consisted of Chlamydia trachomatis serovars B-K, the second of Chlamydia pneumoniae strain IOL-207 and the third of Chlamydia psittaci strain 6 BC. Prototype strains (kindly supplied by Dr. J. Treharne, London) were grown in the yolk sacs of hen eggs. Antigens were semipurified by differential centrifugation. Sera showing IgG and IgM reactivity were further titrated against the individual antigens. IgG antibody titres $\geqslant 32$ were considered positive. ${ }^{8}$

Serology of Herpes simplex virus type-2 (HSV-2), specific IgG was detected by using the HSV-2 specific glycoprotein $\mathrm{G}$ as antigen in an ELISA. Extracts of HSV-2 infected cells were bound to helix pomatia lectin. HSV-2 gG was affinity purified as described by Olofsson et al. ${ }^{9}$ The HSV-2 gG antigen was coated in $0.05 \mathrm{M}$ carbonate buffer, $\mathrm{pH} 9.6$.

\section{Statistical analyses}

The association between the presence of infections, clinical findings and symptoms were determined by the chi square test. The level for statistical significance was set at $0 \cdot 05$.

\section{Results}

A total of 611 women were examined, including 60 women who had never had sexual intercourse. One out of five women had a history of at least one STD (table 2). The proportion of women who could recall a history of any STD increased with age, from $15 \cdot 7 \%$ among the 19 year olds to $33.1 \%(p<0.002)$ among the 25 year olds. The most frequently reported STD was a $C$ trachomatis infection 
Table 2 Reported history of STD, PID and Pap smear (\% of N/n)

\begin{tabular}{|c|c|c|c|c|c|}
\hline & \multirow[b]{2}{*}{$\begin{array}{l}\text { All } \\
n=611(\%)\end{array}$} & \multicolumn{4}{|l|}{ Age-groups } \\
\hline & & $\begin{array}{l}19 \\
n=70(\%)\end{array}$ & $\begin{array}{l}21 \\
n=168(\%)\end{array}$ & $\begin{array}{l}23 \\
n=228(\%)\end{array}$ & $\begin{array}{l}25 \\
n=145(\%)\end{array}$ \\
\hline $\begin{array}{l}\text { C. trachomatis } \\
\text { Condyloma } \\
\text { Herpes } \\
\text { PID } \\
\text { Abnormal }\end{array}$ & $\begin{array}{l}91(14 \cdot 9) \\
59(9 \cdot 7) \\
12(2 \cdot 0) \\
31(5 \cdot 1)\end{array}$ & $\begin{array}{l}8(11 \cdot 4) \\
5(7 \cdot 1) \\
0 \\
2(2 \cdot 9)\end{array}$ & $\begin{array}{c}19(11 \cdot 3) \\
13(7 \cdot 7) \\
0 \\
6(3 \cdot 6)\end{array}$ & $\begin{array}{c}39(17 \cdot 1) \\
22(9 \cdot 6) \\
5(2 \cdot 2) \\
11(4 \cdot 8)\end{array}$ & $\begin{array}{c}25(17 \cdot 2) \\
19(13 \cdot 1) \\
7(4 \cdot 8) \\
12(8 \cdot 3)\end{array}$ \\
\hline $\begin{array}{l}\text { Pap smear } \\
\text { One STD } \\
\geqslant \text { two STD }\end{array}$ & $\begin{array}{c}16(2 \cdot 6) \\
103(16 \cdot 9) \\
41(6 \cdot 7)\end{array}$ & $\begin{array}{l}1(1 \cdot 4) \\
7(10 \cdot 0) \\
4(5 \cdot 7)\end{array}$ & $\begin{array}{c}3(1 \cdot 8) \\
19(11 \cdot 3) \\
9(5 \cdot 4)\end{array}$ & $\begin{array}{c}5(2 \cdot 2) \\
44(19 \cdot 3) \\
13(5 \cdot 7)\end{array}$ & $\begin{array}{c}7(4 \cdot 8) \\
33(22 \cdot 8) \\
15(10 \cdot 3)\end{array}$ \\
\hline
\end{tabular}

Table 3 Present reported symptoms localised to the lower genital tract (\% of $N / n$ )

\begin{tabular}{lcclll}
\hline \multicolumn{5}{c}{ Age-groups } \\
\cline { 3 - 6 } & All & 19 & 21 & 23 & 25 \\
& $n=611(\%)$ & $n=70(\%)$ & $n=168(\%)$ & $n=228(\%)$ & $n=145(\%)$ \\
\hline Itching & $74(12 \cdot 1)$ & $7(10 \cdot 0)$ & $22(13 \cdot 1)$ & $28(12 \cdot 3)$ & $17(11 \cdot 7)$ \\
Discharge & $63(10 \cdot 3)$ & $12(17 \cdot 1)$ & $12(7 \cdot 1)$ & $21(9 \cdot 2)$ & $18(12 \cdot 4)$ \\
Soreness & $36(5 \cdot 9)$ & $2(2 \cdot 8)$ & $9(5 \cdot 4)$ & $12(5 \cdot 3)$ & $13(9 \cdot 0)$ \\
Coital pain & $15(2 \cdot 5)$ & $1(1 \cdot 4)$ & $7(4 \cdot 2)$ & $6(2 \cdot 7)$ & $1(0 \cdot 7)$ \\
Bleedings & $17(2 \cdot 8)$ & 0 & $8(4 \cdot 8)$ & $5(2 \cdot 2)$ & $4(2 \cdot 8)$ \\
Fissures & $18(3 \cdot 0)$ & 0 & $9(5 \cdot 4)$ & $5(2 \cdot 2)$ & $4(2 \cdot 8)$ \\
One symptom & $112(18 \cdot 3)$ & $14(20 \cdot 0)$ & $31(18 \cdot 5)$ & $38(16 \cdot 7)$ & $29(20 \cdot 0)$ \\
?Two symptoms & $49(8 \cdot 0)$ & $4(5 \cdot 7)$ & $14(8 \cdot 3)$ & $18(7 \cdot 9)$ & $13(9 \cdot 0)$ \\
\hline
\end{tabular}

(14.9\%). Three women (0.5\%) had had a $N$ gonorrheae infection.

In all, $26.3 \%$ of the women reported some kind of lower genital tract symptoms (table 3). The reported symptoms were: itching $(12 \cdot 1 \%)$, vaginal discharge $(10 \cdot 3 \%)$, soreness $(5.9 \%)$, painful fissures in the introitus vaginae $(3 \%)$, intermenstrual or coital bleeding $(2 \cdot 8 \%)$ and coital pain $(2 \cdot 5 \%)$.
At the clinical examination (table 4) acetowhite patches on the vulva were observed in $34.8 \%$, papillomatous structure in $29.6 \%$, introital fissures in $6 \%$ and genital warts (condylomata acuminata) in $4 \%$ of cases. A cervical ectopia was noted in $40 \%$ of the women, with the highest prevalence among the youngest women $(50.9 \%) \mathrm{p}=0.0002$. In wet smears lactobacilli were absent in $27.1 \%$ of cases, in $21.7 \%$ of cases leucocytosis was present, a vaginal discharge with a fishy odour was noted in $8.8 \%$, clue cells were present in $6.3 \%$ and pseudohyphae were noted in $8.9 \%$ of cases. No trichomonads were noted.

Altogether, the laboratory tests (culture, PCR, serology) revealed that $45.4 \%$ of these young women had a present or previous STD (table 5). The most prevalent infectious agent was HPV since HPV DNA was detected in $20 \%$ of the women. An atypical Pap smear was found in $3.4 \%$. Chlamydial antibodies were detected in $22.4 \%$ of cases but only $2.7 \%$ of the women had a positive $C$ trachomatis culture. The prevalence of antibodies against HSV-2 increased with age: $4.5 \%$ among the 19 year olds and $11.4 \%(p=$ 0.0006 ) among the 25 year olds.

The associations between the reported lower genital symptoms (discharge, itching and soreness) and the history of $C$ trachomatis, laboratory and clinical findings are presented in table 6.

The complaint of vaginal discharge was associated with a reported history of $C$ trachomatis infection $(\mathrm{p}=0.0002), C$ trachomatis antibodies $(p<0.004)$, present condyloma

Table 4 Clinical findings in vulva, on cervix uteri and in wet smear (\% of $N / n$ )

\begin{tabular}{|c|c|c|c|c|c|}
\hline & \multirow{2}{*}{$\begin{array}{l}\text { No of women } \\
\text { examined }\end{array}$} & \multicolumn{4}{|l|}{ Age-groups } \\
\hline & & 19 & 21 & 23 & 25 \\
\hline $\begin{array}{l}\text { C. acuminata } \\
\text { Present } \\
\text { Acetowhitepatches }\end{array}$ & $\begin{array}{c}n=603 \\
24(4 \cdot 0) \\
n=604 \\
210(34 \cdot 8)\end{array}$ & $\begin{array}{c}\mathrm{n}=69 \\
2(2 \cdot 9) \\
\mathrm{n}=69 \\
20(29 \cdot 0)\end{array}$ & $\begin{array}{c}\mathrm{n}=164 \\
4(2 \cdot 4) \\
\mathrm{n}=165 \\
50(30 \cdot 3)\end{array}$ & $\begin{array}{c}\mathrm{n}=225 \\
10(4 \cdot 4) \\
\mathrm{n}=225 \\
73(32 \cdot 4)\end{array}$ & $\begin{array}{c}\mathrm{n}=145 \\
8(5 \cdot 5) \\
\mathrm{n}=145 \\
67(46 \cdot 2)\end{array}$ \\
\hline $\begin{array}{l}\text { Present } \\
\text { Papillomatous } \\
\text { Structure present } \\
\text { Fissures } \\
\text { Present } \\
\text { Portio-ectopy } \\
\text { Present } \\
\text { Present in wet smear } \\
\text { Lactobacilli } \\
\text { Leucocytes > 5 } \\
\text { Fishy odour } \\
\text { Clue-cells } \\
\text { Pseudohyphae }\end{array}$ & $\begin{array}{l}\mathrm{n}=604 \\
179(29 \cdot 6) \\
\mathrm{n}=603 \\
36(6 \cdot 0) \\
\mathrm{n}=557 \\
223(40 \cdot 0) \\
\mathrm{n}=590 \\
430(72 \cdot 9) \\
128(21 \cdot 7) \\
52(8 \cdot 8) \\
37(6 \cdot 3) \\
53(8 \cdot 9)\end{array}$ & $\begin{array}{l}\mathrm{n}=69 \\
23(33 \cdot 3) \\
\mathrm{n}=69 \\
3(4 \cdot 3) \\
\mathrm{n}=55 \\
28(50 \cdot 9) \\
\mathrm{n}=67 \\
56(83 \cdot 6) \\
14(20 \cdot 9) \\
5(7 \cdot 5) \\
3(4 \cdot 5) \\
2(2 \cdot 9)\end{array}$ & $\begin{array}{c}\mathrm{n}=165 \\
47(28 \cdot 5) \\
\mathrm{n}=164 \\
12(7 \cdot 3) \\
\mathrm{n}=148 \\
77(52 \cdot 0) \\
\mathrm{n}=163 \\
128(78 \cdot 5) \\
36(22 \cdot 0) \\
9(5 \cdot 5) \\
7(4 \cdot 3) \\
5(3 \cdot 0)\end{array}$ & $\begin{array}{l}\mathrm{n}=225 \\
61(27 \cdot 1) \\
\mathrm{n}=225 \\
12(5 \cdot 3) \\
\mathrm{n}=215 \\
77(35 \cdot 8) \\
\mathrm{n}=219 \\
153(69 \cdot 8) \\
49(22 \cdot 4) \\
22(10 \cdot 0) \\
14(6 \cdot 4) \\
21(9 \cdot 6)\end{array}$ & $\begin{array}{l}\mathrm{n}=145 \\
48(33 \cdot 1) \\
\mathrm{n}=145 \\
9(6 \cdot 2) \\
\mathrm{n}=139 \\
41(29 \cdot 5) \\
\mathrm{n}=141 \\
93(65 \cdot 9) \\
29(20 \cdot 5) \\
16(11 \cdot 3) \\
13(9 \cdot 0) \\
25(17 \cdot 7)\end{array}$ \\
\hline
\end{tabular}

Table 5 Laboratory findings by age-group (\% of $N / n$ )

\begin{tabular}{|c|c|c|c|c|c|}
\hline & \multirow{2}{*}{$\begin{array}{l}\text { No of women } \\
\text { examined }\end{array}$} & \multicolumn{4}{|l|}{ Age-groups } \\
\hline & & 19 & 21 & 23 & 25 \\
\hline $\begin{array}{l}\text { C. trachomatis } \\
\text { Culture positive } \\
\text { C. trachomatis } \\
\text { Serology positive } \\
\text { Pap smear } \\
\text { Atypia } \\
\text { HPV-DNA } \\
\text { Positive } \\
H S V-2 \\
\text { Positive } \\
\text { One STD } \\
\geqslant \text { two STD }\end{array}$ & $\begin{array}{c}\mathrm{n}=557 \\
15(2 \cdot 7) \\
\mathrm{n}=584 \\
131(22 \cdot 4) \\
\mathrm{n}=557 \\
19(3 \cdot 4) \\
\mathrm{n}=590 \\
118(20 \cdot 0) \\
\mathrm{n}=584 \\
35(6 \cdot 0) \\
\mathrm{n}=522 \\
142(27 \cdot 2) \\
95(18 \cdot 2)\end{array}$ & $\begin{array}{l}\mathrm{n}=55 \\
3(5 \cdot 5) \\
\mathrm{n}=66 \\
17(25 \cdot 8) \\
\mathrm{n}=55 \\
3(5 \cdot 5) \\
\mathrm{n}=69 \\
11(15.9) \\
\mathrm{n}=66 \\
3(4 \cdot 5) \\
\mathrm{n}=54 \\
17(31.5) \\
10(18.5)\end{array}$ & $\begin{array}{c}\mathrm{n}=148 \\
2(1.4) \\
\mathrm{n}=160 \\
25(15 \cdot 6) \\
\mathrm{n}=148 \\
7(4 \cdot 7) \\
\mathrm{n}=159 \\
25(15 \cdot 7) \\
\mathrm{n}=160 \\
3(1.9) \\
\mathrm{n}=137 \\
24(17 \cdot 5) \\
20(14 \cdot 6)\end{array}$ & $\begin{array}{l}\mathrm{n}=216 \\
8(3 \cdot 7) \\
\mathrm{n}=218 \\
51(23 \cdot 4) \\
\mathrm{n}=215 \\
3(1 \cdot 4) \\
\mathrm{n}=220 \\
39(17 \cdot 7) \\
\mathrm{n}=218 \\
13(6 \cdot 0) \\
\mathrm{n}=201 \\
59(29 \cdot 4) \\
32(15.9)\end{array}$ & $\begin{array}{c}\mathrm{n}=138 \\
2(1 \cdot 4) \\
\mathrm{n}=140 \\
38(27 \cdot 1) \\
\mathrm{n}=139 \\
6(4 \cdot 3) \\
\mathrm{n}=142 \\
43(30 \cdot 3) \\
\mathrm{n}=140 \\
16(11 \cdot 4) \\
\mathrm{n}=130 \\
42(32 \cdot 3) \\
33(25 \cdot 4)\end{array}$ \\
\hline
\end{tabular}


Table 6 Reported symptoms associated with past and present STD and clinical findings

\begin{tabular}{|c|c|c|c|c|c|c|c|c|c|c|c|c|}
\hline & \multicolumn{4}{|c|}{ Discharge } & \multicolumn{4}{|l|}{ Itching } & \multicolumn{4}{|l|}{ Soreness } \\
\hline & yes & no & $\chi^{2}$ & p-value & yes & no & $\chi^{2}$ & p-value & yes & no & $\chi^{2}$ & p-value \\
\hline \multicolumn{13}{|l|}{ Past } \\
\hline Chlamydia history & $\begin{array}{l}21 / 57 \\
(36 \cdot 8)\end{array}$ & $\begin{array}{l}70 / 475 \\
(14 \cdot 7)\end{array}$ & $17 \cdot 5$ & 0.0001 & & & & ns & $\begin{array}{l}11 / 32 \\
(34 \cdot 4)\end{array}$ & $\begin{array}{l}80 / 500 \\
(16 \cdot 0)\end{array}$ & $7 \cdot 1$ & 0.007 \\
\hline Chlamydia serology pos. & $\begin{array}{l}22 / 54 \\
(40 \cdot 7)\end{array}$ & $\begin{array}{l}108 / 475 \\
(22 \cdot 7)\end{array}$ & $8 \cdot 4$ & 0.004 & & & & ns & & & & ns \\
\hline HSV-2 & & & & ns & & & & ns & & & & ns \\
\hline Condyloma & & & & ns & & & & ns & & & & ns \\
\hline Herpes & & & & ns & & & & ns & & & & ns \\
\hline PID & & & & ns & & & & ns & & & & ns \\
\hline Present & & & & & & & & & & & & \\
\hline Condyloma acuminata & $\begin{array}{l}6 / 59 \\
(10 \cdot 2)\end{array}$ & $\begin{array}{l}18 / 488 \\
(3 \cdot 7)\end{array}$ & $5 \cdot 2$ & 0.02 & & & & ns & & & & ns \\
\hline Vulva-fissures & & & & ns & & & & ns & $\begin{array}{l}6 / 34 \\
(17 \cdot 6)\end{array}$ & $28 / 51$ & $8 \cdot 1$ & 0.004 \\
\hline Vulva white-patches & & & & ns & $\begin{array}{l}37 / 71 \\
(52 \cdot 1)\end{array}$ & $\begin{array}{l}161 / 476 \\
(33 \cdot 8)\end{array}$ & 8.9 & 0.003 & & & & ns \\
\hline C. trachomatis culture & & & & ns & & & & ns & & & & ns \\
\hline Cervical HPV DNA pos. & & & & ns & & & & ns & & & & ns \\
\hline Cervical ectopy & & & & ns & & & & ns & & & & ns \\
\hline $\begin{array}{l}\text { Papillomatous structure } \\
\text { Findings in wet smear }\end{array}$ & & & & ns & & & & ns & & & & ns \\
\hline Lack of lactobacilli & $\begin{array}{l}27 / 58 \\
(46 \cdot 6)\end{array}$ & $\begin{array}{l}130 / 477 \\
(273)\end{array}$ & $9 \cdot 2$ & 0.002 & & & & ns & $\begin{array}{l}19 / 33 \\
(57 \cdot 6)\end{array}$ & $\begin{array}{l}138 / 502 \\
(27 \cdot 5)\end{array}$ & 13.5 & 0.0002 \\
\hline Leucocytosis & $\begin{array}{l}20 / 58 \\
(34 \cdot 5)\end{array}$ & $\begin{array}{l}107 / 477 \\
(22 \cdot 4)\end{array}$ & $4 \cdot 1$ & 0.04 & & & & ns & $\begin{array}{l}13 / 33 \\
(39 \cdot 4)\end{array}$ & $\begin{array}{l}114 / 502 \\
(22 \cdot 7)\end{array}$ & $4 \cdot 7$ & 0.03 \\
\hline Pseudohyphae & & & & ns & $\begin{array}{l}12 / 71 \\
(16 \cdot 9)\end{array}$ & $\begin{array}{l}40 \cdot 464 \\
(8 \cdot 6)\end{array}$ & $4 \cdot 8$ & 0.03 & & & & ns \\
\hline Fishy odour & $\begin{array}{l}13 / 58 \\
(22 \cdot 4)\end{array}$ & $\begin{array}{l}39 / 477 \\
(8 \cdot 2)\end{array}$ & $11 \cdot 9$ & 0.005 & & & & ns & $\begin{array}{l}7 / 33 \\
(21 \cdot 2)\end{array}$ & $\begin{array}{l}45 / 50 \\
(9 \cdot 0)\end{array}$ & $5 \cdot 2$ & 0.02 \\
\hline Clue cells & & & & ns & & & & ns & & & & ns \\
\hline
\end{tabular}

acuminata $(p=0.02)$, the absence of lactobacilli $(p=0.002)$, presence of leucocytosis $(p=0.04)$ and fishy odour $(p=0.0005)$. Itching was associated with aceto-white patches on the vulva $(\mathrm{p}<0.003)$ and pseudohyphae $(\mathrm{p}<0.03)$

Soreness was associated with a reported history of $C$ trachomatis $(\mathrm{p}=0.007)$, absence of lactobacilli $(p=0.0002)$, presence of leucocytosis $(\mathrm{p}<0.03)$ and fishy odour $(\mathrm{p}<$ $0.02)$.

We found no significant associations between reported symptoms (discharge, itching and soreness) and the women's own history of condyloma, herpes and pelvic inflammatory disease (PID). There were no associations between symptoms and a positive $C$ trachomatis culture, a presence of cervical HPV-DNA, HSV-2, the occurrence of a cervical ectopy, papillomatous structure on the vulva or clue cells in wet smears.

Antibodies to $C$ pneumoniae (TWAR) were found in $41.8 \%(23 / 55)$ of the virgins and in $39 \cdot 1 \%(207 / 529)$ of the non-virgin group. In the latter group $C$ trachomatis antibodies were found in $20.8 \%(43 / 207)$ of those with concurrent TWAR antibodies and in $27.0 \%$ (87/322) of those without TWAR antibodies, a difference not statistically significant.

\section{Discussion}

In the present population-based study, one fourth of the women reported symptoms from the lower genital tract and itching was the most commonly reported complaint. We found itching to be significantly associated with pseudohyphae, which is in accordance with results from other studies. ${ }^{1011}$ But we also found that itching was associated with acetowhite patches, a sign commonly associated with HPV-infection. ${ }^{512}$ Our findings support earlier observations that itching might be due both to a candidiasis and an HPV infection. ${ }^{13}$ However, on the other hand the aceto-white patches may be due to trauma caused by repeated scratching as a result of itching.

Vaginal discharge is usually associated with lower genital tract infection, ${ }^{2}$ and also with a positive $C$ trachomatis culture. ${ }^{14}{ }^{15} \mathrm{We}$ found that the reported complaint of vaginal discharge was strongly associated with a past $C$ trachomatis infection but not with a present $C$ trachomatis infection. It could be, that in our study there were too few women who had a present $C$ trachomatis infection or that women with a past $C$ trachomatis infection have usually been treated with antibiotics in contrast to women with a present $C$ trachomatis infection and this could influence the vaginal flora. ${ }^{16}$ This argument is supported by our finding that women with a reported vaginal discharge have a lack of lactobacilli indicating a disturbed vaginal flora. It may, however, also be the case that this association is in fact confounded by sexual behaviour. Those patients reporting prior chlamydia trichomatis infection may have more frequent sexual intercourse and more sexual partners as shown in other studies, ${ }^{17} 18$ and therefore be more likely to have clue cells and other causes of a vaginal discharge. The specificity of MIF is a recognised problem, and the possibility of crossreactions with other chlamydia strains has been discussed. ${ }^{19}$ Thus it is important to differentiate antibody reactivity to $C$ trachomatis from the respiratory pathogens $C$ pneumoniae (TWAR) and $C$ psittaci, and all three antigens were included in the test. $C$ psittaci antibodies were very uncommon, and when present occurred at low titre, and did not complicate the assessment of reactivity to $C$ trachomatis. TWAR antibodies, were very common, 
usually occurring at high titre, and the relationship between $C$ trachomatis and TWAR was, therefore, analysed. As chlamydial antibodies can be produced against both sexually transmitted $C$ trachomatis and respiratory infections from $C$ pneumoniae (strain TWAR), correlations between seropositivity and sexual activity can validate the specificity of the method used. In the present study, only one $(1 \cdot 8 \%)$ out of 55 virgins tested was seropositive, as compared with $24.6 \%$ of the sexually experienced women and the prevalence of seropositivity increased with increasing number of lifetime sexual partners though TWAR antibody seroprevalence was the same (40\%) in both groups. However, as there was no difference in $C$ trachomatis seropositivity between women seropositive and those who were seronegative for TWAR, indicating the presence of antibodies to $C$ trachomatis and TWAR antibodies to be independent markers. Thus, the presence of TWAR antibodies should not have confounded the determination of antibodies to $C$ trachomatis. These findings support our view that cross-reactivity with other chlamydial strains is not a problem with the MIF technique used in this study. No samples for Neisseria gonorrhoeae were taken as the prevalence of this infection in Sweden is extremely low (14 cases per 100000 population in 1989).

The reported complaint of soreness was associated with a past chlamydia infection and a disturbed vaginal flora. Both vaginal discharge and soreness were associated with the presence of fishy odour. Clue cells were, however, not associated with vaginal symptoms which is in accordance with other studies. ${ }^{2}$

In conclusion, we have in a populationbased study of young healthy women found that one out of four women had some kind of lower genital tract complaint. Itching was the most commonly reported symptom and was associated with pseudohyphae and acetowhite patches. Reported vaginal discharge and soreness were associated with the history of a past $C$ trachomatis infection and signs of a disturbed vaginal flora.
1 Schafer M-A, Beck A, Blain B, et al. Chlamydia trachomatis: important relationships to race, contraception, lower genital tract infection and papanicolaou smear. $\mathcal{F}$ Pediat 1984;104:141-6.

2 Riordan T, Macauley ME, James JM, et al. A prospective study of genital infections in a family-planning clinic 1 . Microbiological findings and their association with vaginal symptoms. Epidemiol Infect 1990;104:47-53.

$3 \mathrm{Moi} \mathrm{H}$. Prevalence of bacterial vaginosis and its association, and contraceptive methods in women attending sexually transmitted disease and primary health clinics. sexually transmitted disease and prin
Int $\mathcal{Y}$ STD $\mathcal{E}^{\circ} A I D S$ 1990;1:86-94.

4 Phillips RR, Hanff PA, Holmes MD, Wertheimer A Aronson MD. Chlamydia trachomatis cervical infection in women seeking routine gynecologic care: Criteria for selective testing. Am $\mathcal{F}$ Med 1989;86:515-20.

5 Pixley E, Coppleson M. Human papillomavirus infection and genital cancer. In: Gilbert GH, ed. Baillière's Clinical Obstetrics and Gynaecology 1993;7:183-217.

6 Evander M, Edlund $\mathrm{K}$, Bodén E, et al. Comparison of one-step and two-step polymerase chain reaction with degenerate general primers in a population-based study of human papillomavrus infection in young Swedish women. F Clin Microbiol 1992;30:987-92.

7 Ripa KT, Mårdh P-A. Cultivation of Chlamydia trachomatis in cycloheximide-treated McCoy cells. $\mathcal{F}$ Clin Microbiol 1977;6:328-31.

8 Osser S, Persson K. Immune Response to genital chlamydial infection and influence of Chlamydia pneumoniae (TWAR) antibodies. Eur 7 Clin Microbiol Infect Dis 1989 8:532-5.

9 Olofsson S, Lundström M, Marsden H, Jeansson S, Vahlne A. Characterization of a herpes simplex virus type2-specified glycoprotein with affinity for N-acetylgalactosamine-specific lectins and its identification as 92K or gG. $\mathcal{f}$ Gen Virol $1986 ; 67: 737-44$

10 Odds FC, Webster CE, Mayuranathan P, Simmons PD. Candida concentrations in the vagina and their association with signs and symptoms of vaginal candidosis. tion with signs and symptoms of vag

11 Spinillo A, Pizzoli G, Colonna L, Nicola S, De Zeta F, Guaschino S. Epidemiologic characteristics of women with idiopathic recurrent vulvovaginal candidiasis. Obstet Gynecol 1993;81:721-7.

12 Petersen CS, Albrechtsen J, Larsen J, et al. Subclinical human virus infection in condylomata acuminata patients attending a VD clinic. Acta Dermatol Venereol 1991;71:252-5.

13 Bodén E, Eriksson A, Rylander E, v Schoultz B. Clinical characteristics of papilloma virus vulvo vaginitis; an entity with oncogenic potential. Acta Obstet Gynecol Scand 1988;67:145-51.

14 Bro F, Juul S. Predictors of Chlamydia trachomatis infection in women in general practice. Fam Pract 1990;7:138-43.

15 Harrison RH, Costin M, Meder JB, et al. Cervical chlamydia trachomatis infection in university women: dia trachomatis infection in university women: Relationship to history, contraception, ectop

16 Mårdh P-A. The vaginal ecosystem. Am $\mathcal{f}$ Obstet Gynecol 1991;165:1163-8.

17 Johnson BA, Poses RM, Fortner CA, Meier FA, Dalton HP. Derivation and validation of a clinical diagnostic model for chlamydial cervical infection in University women. $F A M A$ 1990;264:3161-5.

18 Weinstock HS, Bolan GA, Kohn R, Balladares C, Back A, Oliva G. Chlamydia trachomatis infection in women: a need for universal screening in high prevalence populations? Am 7 Epidemiol 1992;135:41-7.

19 Vetter KM, Barnes RC, Oberle MW, Rosero-Bixby L Schachter J. Seroepidemiology of chlamydia in Costa Rica. Genitourin Med 1990;66:182-8. 